\title{
PROCESSOS CONTRA MÉDICOS
}

Vivemos momento em que vicejam processos e movimento de verdadeiro terrorismo contra a classe Médica. O Médico, vítima das circunstâncias, sente-se acuado, temeroso e perplexo. Como precaver-se contra esta epidemia?

Excelente conclave foi realizado no Rio de Janeiro, organizado pela Sociedade de Ginecologia e Obstetrícia com temas muito bem selecionados, com a participação de Advogados, Peritos, Juízes, Conselheiros do CRM-RJ que se sucederam brindando os participantes com exposições de alta qualidade.

Algumas boas conclusões puderam ser extraídas destas palestras. O Médico não deve temer processos quando sua condutas forem pautadas pela seriedade, pelo desvelo, pelo respeito para com os pacientes (bom relacionamento médico-paciente), com prática médica atualizada e obediente às condutas consagradas, sem improvisações temerosas.

Há crescente, inconseqüente, desregrada "indústria" de processos contra médicos com meridiana finalidade: conseguir algum retorno financeiro. Como foi dito, na Sociedade Moderna, os médicos são considerados "alvo" fácil.

O que vemos? Os "clientes” (em geral com situação financeira desfavorável), incitados por alguns advogados, freqüentemente também ávidos de "alguma remuneração extra", acreditam firmemente na possibilidade de obter vantagem financeira. Outras vezes procuram estes "clientes" organizações, cuja única finalidade é denegrir e agredir furiosamente a classe médica. São as chamadas associações contra erros médicos. Alegam sempre pretensas falhas e o que é insucesso torna-se para estes grupos erro médico. Infelizmente, vemos a mídia incorporar-se (com interesses por vezes velados) e divulgar de maneira sensacionalista estes alegados erros médicos.

O CRM-RJ, em louvável atitude, coloca-se firmemente contrário à pressão exercida para estabelecimento dos chamados Seguros-Médicos. Na visão, no nosso entender certíssima do CRM, estes Seguros alimentariam a ganância financeira e propiciariam aparecimento de múltiplas e infundadas ações contra os médicos.

Na eventualidade de alguma ação judicial, deverá o médico ser bem assessorado por advogado sério e competente. Multiplicam-se, aqui também, os causídicos despreparados e também ávidos de remuneração extra.

Os eminentes Juízes presentes no Conclave alertaram os médicos: deveriam postular junto ao Parlamento elaboração de Leis especificas normatizando judicialmente a atividade médica. Para estes magistrados, os médicos não poderiam ser rotulados como meros prestadores de serviço e serem assim regidos pelo Código de Defesa do Consumidor. Os médicos não mercadejam objetos. Lidam com pessoas e o que de mais precioso elas possuem: a Saúde.

Ficou patente que médicos que agem com seriedade, que desenvolvem suas atividades lastreados em Medicina de qualidade, que respeitam seus pacientes, estes profissionais poderão se tranqüilizar. Na sociedade hodierna, ávida de lucros, sem ideais elevados, ou mesmo sem nenhum, o medico poderá ser acionado, mas, com legislação específica a ser prontamente elaborada (que os órgãos de Classe se mobilizem) os que um dia juraram seguir o Código Hipocrático poderão aquietar-se, pois nada lhes poderá ser imputado.

\section{A Diretoria}

